\title{
Development of a Scale to Analyze the Perception of Aromatic Black Rice Growers towards Mission Organic Value Chain Development Scheme
}

Meghajit Sharma Shijagurumayum¹, M.T. Lakshminarayan², T.L. Mohankumar ${ }^{3}$

10.18805/ag.D-5345

\begin{abstract}
Background: An attempt is made in the present study to develop and standardized scale to analyse the perception of aromatic black rice growers towards the Mission Organic Value Chain Development Scheme (MOVCDS) which is implemented in North Eastern states of India.

Methods: A perception scale was developed and administered to 35 aromatic black rice growers in Imphal West district of Manipur. Based on the cumulated score, the aromatic black rice growers were categorized as poor, good and better level of perception towards MOVCDS considering mean and half standard deviation as a measure of check.

Result: The developed perception scale was found to be highly reliable and valid. The final perception scale consists of 18 statements, of which 13 statements are positive and the remaining five statements are negative. The results revealed that an equal number of aromatic black rice growers (34.29\% each) had good and better perception towards MOVCDS, whereas the remaining 31.42 per cent of the aromatic black rice growers had poor perception towards MOVCDS

Key words: Aromatic black rice, Organic, Perception, Reliability, Validity.
\end{abstract}

\section{INTRODUCTION}

The Mission Organic Value Chain Development for North Eastern Region (MOVCD-NER) is a Central Government Scheme implemented by the Ministry of Agriculture and Farmers Welfare. This is a sub-mission scheme under the National Mission for Sustainable Agriculture (NMSA) implemented for promoting organic cultivation practices among farmers in Arunachal Pradesh, Assam, Manipur, Meghalaya, Mizoram, Nagaland, Sikkim and Tripura states. During phase I, a total area of 45,918 ha was planned to be covered under MOVCD-NER and during the phase II (201819 to 2020-2021) the scheme is targeted to cover 50,000 ha in the North Eastern States of the country. However, the project implementation got delayed by two years. Phase I was initiated during 2017-18 and ended during 2019-20 covering 2000 ha and phase II will be implemented from 2021-2022 covering 50,000 ha.

The scheme is implemented during $12^{\text {th }}$ plan period by Manipur Organic Mission Agency (MOMA) in Manipur aiming at promotion and production of certified organic commodities focusing on export oriented crops viz., black aromatic rice, ginger, Tamenglong orange, King chilli, Kachai lemon and pineapple. The MOMA is conducting various production and extension activities, such as providing training on package of practices for organic cultivation and identification of farmer cluster groups through which the organic practices, the information and technical know-how is expected to be tickled down.

Despite the efforts made by Mission Organic Value Chain Development Scheme (MOVCDS) in promoting organic cultivation of black rice, what is needed to be looked upon is the fact that Black rice regardless of its importance
1Department of Agricultural Extension, University of Agricultural Sciences, Bangalore-560 065, Karnataka, India.

2University Examination Centre, University of Agricultural Sciences, Bangalore-560 065, Karnataka, India.

${ }^{3}$ Department of Agricultural Statistics, Applied Mathematics and Computer Sciences, University of Agricultural Sciences, Bangalore560 065, Karnataka, India

Corresponding Author: Meghajit Sharma Shijagurumayum, Department of Agricultural Extension, University of Agricultural Sciences, Bangalore-560 065, Karnataka, India.

Email: meghajit59@gmail.com

How to cite this article: Shijagurumayum, M.S., Lakshminarayan, M.T. and Mohankumar, T.L. (2022). Development of a Scale to Analyze the Perception of Aromatic Black Rice growers Towards Mission Organic Value Chain Development Scheme. Agricultural Science Digest. DOI: 10.18805/ag.D-5345.

Submitted: 12-04-2021 Accepted: 15-12-2021 Online: 03-03-2022

and superior nutritional benefits have not been commercialised to the extent which it needs to be. Owing to the reason that farmers perceived cultivating white rice to be more economically rewarding. Traditionally in Manipur black rice is often cultivated and grown in smaller areas or plots. Moreover, organic cultivation has often been criticised on the grounds of lower productivity as compared to the conventional cultivation methods. The present study was thus, built around the question regarding the effectiveness of the scheme in persuading farmers in cultivating a seemingly minor crop on a larger scale coupled with an organic approach. In this backdrop the present study is undertaken with the following specific objectives: 
Development of a Scale to Analyze the Perception of Aromatic Black Rice growers Towards Mission Organic Value Chain...

- To develop and standardize a scale to analyse the perception of aromatic black rice growers towards Mission Organic Value Chain Development Scheme.

- To analyse the perception of aromatic black rice growers towards Mission Organic Value Chain Development Scheme.

\section{MATERIALS AND METHODS}

The present study was carried out during 2020-21 for developing and standardized scale to analyse the perception of aromatic black rice growers towards MOVCDS. The developed scale was used to analyse the perception of aromatic black rice growers towards MOVCDS in the state of Manipur. Thirty five aromatic black rice growers from Imphal West district of Manipur were interviewed for the purpose. Based on the cumulated score, the aromatic black rice growers were categorized as poor, good and better level of perception towards MOVCDS considering mean and half standard deviation as a measure of check.

\section{RESULTS AND DISCUSSION}

Development of scale to analyse the perception of aromatic black rice growers towards MOVCDS

Perception of the aromatic black rice growers towards MOVCDS was been operationally defined as 'The degree to which an individual has understood the three components (production, supporting and processing and marketing) of value addition activities of MOVCDS. The method of summated rating scale suggested by Likert (1932) and Edwards (1969) were followed in the development of the perception scale following seven stages viz., (1) identification of components, of MOVCDS (2) collection of statements, (3) editing of statements, (4) relevancy test, (5) item analysis, (6) reliability and (7) validity.

\section{Identification of components of MOVCDS}

Three components (production, supporting, processing and marketing) relating to the value chain activities of MOVCDS were identified were identified for the developing perception statements to analyse the perception of aromatic black rice growers towards MOVCDS.

\section{Collection of perception statements}

The second step is the collection of perception statements for analysing the perception of aromatic black rice growers towards MOVCDS.A tentative list of 36 perception statements/items classified under three components (production, supporting, processing and marketing) of value chain activities were collected through extensive review of literature and by consulting the social scientists and MOVCDS officials.

\section{Editing of perception statements}

Thirty six perception statements were edited as per the 14 criteria enunciated by Edwards (1969) and Thurstone and Chave (1929). As a consequence, two perception statements were eliminated and the remaining 34 perception statements were included for the study.

\section{Relevancy test}

Thirty four statements were sent to 110 experts in the field of social sciences working in State Agricultural Universities, Indian Council of Agricultural Research Institutes and Development Departments, to critically evaluate the relevancy of each statement viz., most relevant (MR), relevant (R), somewhat relevant (SWR), less relevant (LR) and not relevant (NR) with the score of 5,4,3,2 and 1, respectively. The judges were also requested to make necessary modifications and additions or deletion of statements if they desired to. A total of 66 judges returned the questionnaires duly completed and these 66 questionnaires were considered for further processing.

From the data gathered, 'Relevancy Percentage (RP)' and Mean Relevancy Score (MRS)' were worked out for all the 34 perception statements. Using RP and MRS, the individual perception statements were screened for relevancies using the following formulae.

a) Relevancy percentage (RP): It was obtained by using the following formula:

$\mathrm{RP}=$

$$
\frac{\mathrm{MR} \times 5+\mathrm{R} \times 4+\mathrm{SWR} \times 3+\mathrm{LR} \times 2+\mathrm{NR} \times 1 \times 100}{\text { Maximum possible score }}
$$

b) Mean relevancy score (MRS): It was worked out using the following formula:

MRS =

$$
\frac{M R \times 5+R \times 4+S W R \times 3+L R \times 2+N R \times 1}{\text { Number of judges responded }}
$$

Accordingly, the perception statements having 'relevancy percentage' of 75 per cent and above and 'mean relevancy score' of 3.75 and above were considered for final selection. Accordingly, 26 perception statements were retained after relevancy test and these statements were suitably modified and written as per the comments of the judges wherever applicable.

\section{Item analysis}

Twenty six perception statements were subjected to item analysis to delineate the items based on the extent to which they can differentiate the respondent having better perception from the respondent with poor perception regarding MOVCDS.

A sample of 35 aromatic black rice growers from nonsample area viz., Imphal West district of Manipur state were chosen for the study. The respondents were asked to indicate their degree of agreement or disagreement with each statement on a five-point continuum ranging from 'strongly agree' to 'strongly disagree'. Based upon the total score, the respondents were arranged in descending order. The top 25 per cent of the respondents with their total scores were considered as the high group and the bottom 25 per cent as the low group. These two groups provided criterion groups in terms of evaluating the individual statements. 
Development of a Scale to Analyze the Perception of Aromatic Black Rice growers Towards Mission Organic Value Chain...

Thus, out of 35 aromatic black rice growers to whom the items were administered for item analysis, eight respondents with highest and eight respondents with lowest scores were used as criterion groups to evaluate individual items. The critical ratio, that is, the ' $\mathrm{t}$ ' value which analyses the extent to which a given statement differentiates between the better and poor perception groups of aromatic black rice growers for each statement, was calculated by using the following formula:

$$
t=\frac{\bar{X}_{H}-\bar{X}_{L}}{\sqrt{\frac{\sum X_{H}^{2}-\frac{\left(\sum X_{H}\right)^{2}}{n} \times \sum X_{L}^{2}-\frac{\left(\sum X_{L}\right)^{2}}{n}}{n(n-1)}}}
$$

Where,

$\overline{\mathrm{X}} \mathrm{H}=$ The mean score on given statement of the high group. $\bar{X} L=$ The mean score on given statement of the low group. $\Sigma \mathrm{X} 2 \mathrm{H}=$ Sum of squares of the individual score on a given statement for high group.
$\Sigma X 2 L=$ Sum of squares of the individual score on a given statement for low group.

$\mathrm{n}=$ Number of respondents in each group.

$\sum=$ Summation.

$\mathrm{t}=$ The extent to which a given statement differentiates between the high and low groups.

After computing the ' $t$ ' value for all the 26 perception statements, 18 perception statements (six statements each under production, supporting and processing and marketing components) with ' $t$ ' value equal to or greater than 1.67 were selected for the final perception scale. The tabulated values are presented in Table 1.

\section{Reliability}

Reliability refers to precision of the scale constructed for any purpose. A reliability test will be reliable when it gives the same repeated result under the same conditions. In any social science research, a newly constructed scale has to be tested for its reliability before it is used. The split-half

Table 1: Perception statements with relevancy percentage, mean relevancy score and calculated ' $t$ ' value.

\begin{tabular}{|c|c|c|c|}
\hline Perception statements & $\begin{array}{l}\text { Relevancy } \\
\text { percentage }\end{array}$ & $\begin{array}{l}\text { Mean relevancy } \\
\text { score }\end{array}$ & $\begin{array}{l}\text { Calculated } \\
\text { 't' value }\end{array}$ \\
\hline MOVCDS aims at development of certified organic production in a value chain mode & 90.60 & 4.53 & $4.00^{* *}$ \\
\hline $\begin{array}{l}\text { More number of black rice growers have shifted from organic to chemical } \\
\text { farming after the implementation of MOVCDS }\end{array}$ & 87.27 & 4.36 & $3.96^{* *}$ \\
\hline $\begin{array}{l}\text { MOVCDS empowers black rice growers with programme ownership by organizing } \\
\text { them into Farmers Interest Groups (FIGs) at village level and federated into } \\
\text { Farmers Producers Companies (FPCs) at District level }\end{array}$ & 85.45 & 4.27 & $2.56^{\star *}$ \\
\hline Farmers cluster provides an opportunity for its members to develop leadership qualities & 84.55 & 4.23 & $2.30^{* *}$ \\
\hline Farmers clusters has not provided platform for sharing experience among the members & 86.06 & 4.30 & $3.19^{* *}$ \\
\hline $\begin{array}{l}\text { MOVCDS develops rice production clusters with necessary infrastructural, } \\
\text { technical and financial support }\end{array}$ & 80.91 & 4.05 & $1.81^{*}$ \\
\hline $\begin{array}{l}\text { Crop planning and time management are not followed effectively followed by } \\
\text { Black rice growers by participating in the value chain activities of MOVCDS }\end{array}$ & 85.99 & 4.29 & $2.31^{*}$ \\
\hline MOVCDS facilitate farmers with untimely supply of quality seeds & 80.00 & 4.00 & $1.71^{*}$ \\
\hline MOVCDS is emphasizing the farmers to use less of organic manure to black rice & 84.56 & 4.23 & $2.29^{*}$ \\
\hline MOVCDS is advocating excessive use of fertilizers (inorganic manure) to black rice & 80.30 & 4.02 & $1.77^{*}$ \\
\hline $\begin{array}{l}\text { Participating in value chain activities of MOVCDS has not helped the black rice } \\
\text { growers to have strong research and extension linkages }\end{array}$ & 83.94 & 4.20 & $2.29^{*}$ \\
\hline $\begin{array}{l}\text { Outreach activities (demonstrations, training, field visits, field days etc.) of } \\
\text { MOVCDS has increased the adoption of more organic farming practices }\end{array}$ & 82.73 & 4.14 & $2.22^{*}$ \\
\hline $\begin{array}{l}\text { Organic bazaars are established to function as collection centres between the } \\
\text { farm gate and processing infrastructures }\end{array}$ & 84.68 & 4.27 & $2.32^{*}$ \\
\hline $\begin{array}{l}\text { MOVCDS facilitates partnerships and trade relations between FPCs and organic } \\
\text { businesses for promoting domestic and exports markets }\end{array}$ & 80.30 & 4.02 & $1.77^{*}$ \\
\hline $\begin{array}{l}\text { MOVCDS has created awareness among public by giving wide publicity through } \\
\text { printed literature, films and local advertisements for promoting the sale of } \\
\text { organic black rice }\end{array}$ & 85.23 & 4.26 & $2.41^{* *}$ \\
\hline $\begin{array}{l}\text { MOVCDS markets the organic produce through direct retail, farmer markets, } \\
\text { on-line chain and tying up with domestic retail chains and exporters }\end{array}$ & 81.99 & 4.09 & $2.11^{*}$ \\
\hline $\begin{array}{l}\text { Trade fairs/organic festivals have been organised under MOVCDS for effective } \\
\text { marketing of organic black rice among trading fraternity and value chain operators }\end{array}$ & 82.67 & 4.13 & $2.28^{*}$ \\
\hline MOVCDS enables Manipur to evolve its own brand for organic black rice & 81.52 & 4.08 & $2.02^{*}$ \\
\hline
\end{tabular}


Development of a Scale to Analyze the Perception of Aromatic Black Rice growers Towards Mission Organic Value Chain...

method was employed to test the reliability of the perception scale. The value of correlation coefficient was 0.5518 and this was further corrected by using Spearman Brown formula to obtain the reliability coefficient of the whole set. The ' $r$ ' value of the scale was 0.771 , which was significant at one per cent level indicating the high reliability of the scale. It was concluded that the perception scale constructed was reliable.

a) Half test reliability formula:

Where,

$$
r_{1 / 2}=\frac{N\left(\sum X Y\right)-\left(\sum X\right)\left(\sum Y\right)}{\left(N \sum X^{2}-\sum X^{2}\right)\left(N \sum Y^{2}-\left(\sum Y\right)^{2}\right)}
$$

$\Sigma X=$ Sum of the scores of the odd number items

$\sum Y=$ Sum of the scores of the even number items

$\Sigma X^{2}=$ Sum of the squares of the odd number items

$\Sigma Y^{2}=$ Sum of the squares of the even number items.

b) Whole test reliability formula:

$$
r_{1 / 1}=\frac{2 r_{1 / 2}}{1+r_{1 / 2}}
$$

Where,

$r_{1 / 2}=$ Half test reliability.

\section{Validity}

It refers to how well a scale analyses what it is purported to measure. The square root of whole test reliability value $\left(r_{1 / 2}\right)$ gives the validity value. The data was subjected to statistical validity, which was found to be 0.8430 . Hence, the validity coefficient was also found to be appropriate and suitable for the tool developed. Thus, the developed scale to analyse perception of beneficiary aromatic black rice growers towards MOVCDS.

\section{Administration of perception scale and method of scoring}

The final perception scale consists of 18 statements (Table 2) for determining the perception of aromatic black rice growers. The response was collected on a five-point continuum, namely, strongly agree, agree, undecided, disagree and strongly disagree with assigned score of

\begin{tabular}{|c|c|c|c|c|c|}
\hline Perception statement & SA & A & UD & D & SD \\
\hline \multicolumn{6}{|l|}{ MOVCDS aims at development of certified organic production in a value chain mode $(+)$} \\
\hline \multicolumn{6}{|l|}{$\begin{array}{l}\text { More number of black rice growers have shifted from organic to chemical farming } \\
\text { after the implementation of MOVCDS }(+)\end{array}$} \\
\hline \multicolumn{6}{|l|}{$\begin{array}{l}\text { MOVCDS empowers black rice growers with programme ownership by organizing } \\
\text { them into Farmers Interest Groups (FIGs) at village level and federated into Farmers } \\
\text { Producers Companies (FPCs) at District level }(+)\end{array}$} \\
\hline \multicolumn{6}{|l|}{ Farmers cluster provides an opportunity for its members to develop leadership qualities $(+)$} \\
\hline \multicolumn{6}{|l|}{ Farmers clusters has not provided platform for sharing experience among the members (-) } \\
\hline \multicolumn{6}{|l|}{$\begin{array}{l}\text { MOVCDS develops rice production clusters with necessary infrastructural, technical } \\
\text { and financial support }(+)\end{array}$} \\
\hline \multicolumn{6}{|l|}{$\begin{array}{l}\text { Crop planning and time management are not followed effectively followed by black } \\
\text { rice growers by participating in the value chain activities of MOVCDS (-) }\end{array}$} \\
\hline \multicolumn{6}{|l|}{ MOVCDS facilitate farmers with untimely supply of quality seeds (-) } \\
\hline \multicolumn{6}{|l|}{ MOVCDS is emphasizing the farmers to use less of organic manure to black rice $(+)$} \\
\hline \multicolumn{6}{|l|}{ MOVCDS is advocating excessive use of fertilizers (inorganic manure) to black rice (-) } \\
\hline \multicolumn{6}{|l|}{$\begin{array}{l}\text { Participating in value chain activities of MOVCDS has not helped the black rice growers } \\
\text { to have strong research and extension linkages (-) }\end{array}$} \\
\hline \multicolumn{6}{|l|}{$\begin{array}{l}\text { Outreach activities (demonstrations, training, field visits, field days etc.) of MOVCDS } \\
\text { has increased the adoption of more organic farming practices }(+)\end{array}$} \\
\hline \multicolumn{6}{|l|}{$\begin{array}{l}\text { Organic bazaars are established to function as collection centres between the farm } \\
\text { gate and processing infrastructures }(+)\end{array}$} \\
\hline \multicolumn{6}{|l|}{$\begin{array}{l}\text { MOVCDS facilitates partnerships and trade relations between FPCs and organic } \\
\text { businesses for promoting domestic and exports markets }(+)\end{array}$} \\
\hline \multicolumn{6}{|l|}{$\begin{array}{l}\text { MOVCDS has created awareness among public by giving wide publicity through } \\
\text { printed literature, films and local advertisements for promoting the sale of organic } \\
\text { black rice }(+)\end{array}$} \\
\hline \multicolumn{6}{|l|}{$\begin{array}{l}\text { MOVCDS markets the organic produce through direct retail, farmer markets, } \\
\text { on-line chain and tying up with domestic retail chains and exporters }(+)\end{array}$} \\
\hline \multicolumn{6}{|l|}{$\begin{array}{l}\text { Trade fairs/organic festivals have been organised under MOVCDS for effective } \\
\text { marketing of organic black rice among trading fraternity and value chain operators (+) }\end{array}$} \\
\hline MOVCDS enables Manipur to evolve its own brand for organic black rice $(+)$ & & & & & \\
\hline
\end{tabular}

Table 2: Scale to analyse the perception of aromatic black rice growers towards MOVCDS.

$\mathrm{SA}=$ Strongly disagree; $\mathrm{A}=$ Agree; UD=Undecided; $\mathrm{D}=$ Disagree; $\mathrm{SD}=$ Strongly disagree. 
Development of a Scale to Analyze the Perception of Aromatic Black Rice growers Towards Mission Organic Value Chain...

Table 3: Overall perception of black aromatic rice growers towards MOVCDS.

\begin{tabular}{lcc}
\hline Perception categories & \multicolumn{2}{c}{ Aromatic black rice growers } \\
\cline { 2 - 3 } & Number & Per cent \\
\hline Poor $(<49.25$ score) & 10 & 28.57 \\
Good (49.25 to 55.77 score) & 11 & 31.43 \\
Better $(>55.77$ score) & 14 & 40.00 \\
Total & 35 & 100.00 \\
\hline
\end{tabular}

Mean $=52.51 ;$ Standard deviation $=6.52$.

$5,4,3,2$ and 1 , respectively for positive perception statements and the score is reversed for negative statements. Of the 18 perception statements, 13 are positive statements and the remaining five are negative perception statements. The perception score of a respondent was calculated by adding up the scores obtained by him/her on all items/statements. The perception score of this scale ranges from a minimum of 18 to a maximum of 90 . Based on the mean (52.51) and half standard deviation (3.26), the respondents were categorized into three perception categories, viz., poor, good and better. Higher score on this scale indicates that the respondent has better perception towards MOVCDS and lower score on the perception scale denotes that respondent has poor perception towards MOVCDS.

\section{Perception of aromatic black rice growers towards MOVCDS}

The perception scale was administered to 35 aromatic black rice growers in Imphal West district of Manipur state during 2020-21. The results revealed that an equal number of aromatic black rice growers $(34.29 \%$ each) had good and better perception towards MOVCDS, whereas the remaining
31.42 per cent of the aromatic black rice growers had poor perception towards MOVCDS (Table 3). It can be inferred from the research results that a majority of the aromatic black rice growers $(68.58 \%)$ had good to better perception towards MOVCDS. The aromatic black rice growers had good to better perception in respect of production and supporting components, while poor perception was observed in respect of processing and marketing component. More or less similar findings were reported by Naveen et al. (2018).

\section{CONCLUSION}

The perception scale developed is found to be reliable and valid; hence the developed scale could be used to analyse the perception of aromatic black rice growers towards MOVCDS. On administration of the perception scale to the aromatic black rice growers in Imphal West district, it was found that a vast majority of aromatic black rice growers $(68.58 \%)$ had good to better perception towards MOVCDS.

\section{Conflict of interest: None.}

\section{REFERENCES}

Edwards, A.L. (1969). Techniques of attitude scale construction. VIkils, Feger and Simons Private Limited, 9, Sport Road, Ballard Estate, Bombay.

Likert, R.A. (1932). A technique for the assessment of attitudes. Archives of Psychology, New York. 140.

Naveen Kumar, P., Narasimha, N. and Lakshminarayan, M.T. (2018). Development of a scale to analyse the well-being of farmers in Kolar district of Karnataka. Journal of Scientific Research and Reports. 19(2): 1-7.

Thurstone, L.L. and Chave, E.J. (1929). The assessment of attitude, Chicago, University Press, United States of America. 39-40. 